Rev. Biol. Neotrop. 9(2): 2012

\title{
STUDO DA TOXICIDADE GENÉTICA DE EFAVIRENZ (EFV) E FUMARA- TO DE TENOFOVIR DESOPROXILA (TDF) EM CÉLULAS SOMÁtICAS DE DROSOPHILA MELANOGASTER
}

\author{
GENETIC TOXICITY STUDY OF EFAVIRENZ (EFV) AND TENOFOVIR DI- \\ SOPROXIL FUMARATE (TDF) IN SOMATIC CELLS OF DROSOPHILA \\ MELANOGASTER
}

\section{Aroldo Vietra De Moraes fillo}

Endereço atual/current address: Departamento de Bioquímica e Biologia Molecular, Instituto de Ciências Biológicas, Universidade Federal de Goiás, Campus II, Laboratório de Genética Toxicológica, Sala 103, Goiânia, Goiás, Brasil / Department of Biochemistry and Molecular Biology, Institute of Biological Sciences, Federal University of Goiás, Laboratory of Toxicology Genetic, Room 103, Goiânia, Goiás, Brazil; e-mail: kenya@icb.ufg.br

Dissertação de Mestrado/Master Dissertation: Programa de Pós-Graduação em Biologia - área de concentração: Biologia Celular e Molecular, Universidade Federal de Goiás, Goiânia, Goiás, Brasil / Postgraduate Program in Biology - area of concentration: cellular and molecular biology, Federal University of Goiás, Goiânia, Goiás, Brazil.

Defendida/Defended: 06.II.2013

Orientador/Advisor: Profa. Dra. Kênya Silva Cunha, Departamento de Bioquímica e Biologia Molecular, Instituto de Ciências Biológicas, Universidade Federal de Goiás, Goiânia, Goiás, Brasil/ Department of Biochemistry and Molecular Biology, Institute of Biological Sciences, Federal University of Goiás, Goiânia, Goiás, Brazil.

Resumo: Os medicamentos antirretrovirais surgiram para impedir a multiplicação do vírus HIV no organismo, reduzindo a sua virulência, porém sem eliminá-lo das células infectadas. Estes medicamentos aumentaram o tempo e a qualidade de vida dos pacientes com AIDS. Dentro deste contexto, o Efavirenz (EFV) é inibidor da transcriptase reversa não-análogo de nucleosídeo. O Fumarato de Tenofovir Desoproxila (TDF), pró-fármaco oral de tenofovir, é análogo da adenosina 5 `-monofosfato, pertencente à classe de inibidores da transcriptase reversa análogos de nucleotídeos. Estes fármacos atuam nos mecanismos de replicação do HIV, inibindo a ação da transcriptase reversa e, consequentemente, impedindo a síntese de DNA viral. Com o intuito de avaliar o potencial tóxico e tóxico genético do EFV e do TDF, utilizou-se o Teste para Detecção de Mutação e Recombinação Somática (SMART) em Drosophila melanogaster. Larvas de $3^{\circ}$ estágio oriundas do Cruzamento Padrão (ST - standard cross) entre machos $m$ wh e fêmeas $\mathrm{fl}^{3}$, foram tratadas com soluções de EFV e TDF, assim como com água destilada (controle negativo), por aproximadamente $48 \mathrm{~h}$ (tratamento crônico), isto é, até atingirem o estágio de pupa. Essas linhagens são portadoras de genes marcadores específicos, localizados no braço esquerdo do cromossomo 3, que permitem monitorar eventos relacionados com mutação gênica, aberrações cromossômicas e recombinação mitótica. O diagnóstico estatístico foi obtido pelo teste binomial condicional. Os resultados demonstraram que o EFV foi tóxico em altas concentrações, mas não induziu eventos tóxico genéticos. Inversamente, o TDF não apresentou toxicidade nas concentrações testadas, porém apresentou indução de 
efeitos tóxico genéticos em todas as concentrações, com prevalência dos eventos recombinogênicos. Então, torna-se fundamental analisar constantemente o risco/benefício de medicamentos isolados e identificar a atividade tóxica e tóxico-genética de cada fármaco com o intuito de assegurar qualidade de vida aos pacientes que fazem uso de monoterapias e oferecer suporte para as investigações com as terapias que utilizam combinações de antirretrovirais.

Palavras-chave: Efavirenz, fumarato de tenofovir desoproxila e SMART.

AвSTRACT: The antiretroviral drugs appeared to prevent the multiplying HIV virus in the body, reducing its virulence, but not eliminate it from infected cells. These drugs increase the length and the quality of life of AIDS patients. In this context, Efavirenz (EFV) is nonnucleoside reverse transcriptase inhibitors. The Tenofovir Disoproxil Fumarate (TDF), oral prodrug of tenofovir, is analogue of adenosine 5 'monophosphate, belonging to the class of nucleotide reverse transcriptase inhibitors. These drugs act on the mechanisms of HIV replication by inhibiting the action of reverse transcriptase and thus preventing viral DNA synthesis. In order to assess the toxic and toxic-genetic potential of EFV and TDF, the present study used the Test for Detection of Somatic Mutation and Recombination (SMART) in Drosophila melanogaster. 3rd stage larvae originating from standard cross (ST) between males $\mathrm{mwh}$ and females $\mathrm{fl}^{3}$, were treated with solution of EFV and TDF and distilled water (negative control), for approximately 48 hours (chronic treatment) until they reach the pupal stage. These strains are carriers of specific gene markers, located on the left arm of chromosome 3, which allow you to monitor events related to mutation, mitotic recombination and chromosome aberrations. The statistical diagnosis was obtained by conditional binomial test. In this work, the results demonstrated that the EFV was toxic in high concentrations, but showed no induction of toxic genetic events. Inversely, the TDF showed no toxicity at the concentrations tested, but was showed induction of toxic genetic events at all concentrations, with a prevalence of recombinogenic events. Then, it is essential to analyze constantly the effects risk/benefit of isolated drugs and identify toxic and toxic genetic activity of each drug in order to ensure the quality of life for patients who use monotherapies and offers support for investigations with therapies that use combinations of antiretroviral drugs.

KEY woRDs: Efavirenz, tenofovir disoproxil fumarate and SMART. 